\title{
PEMUATAN KETENTUAN PIDANA DALAM \\ PERATURAN PEMERINTAH PENGGANTI UNDANG-UNDANG
}

Loading of Criminal Provisions in Government Regulation in Lieu of Law

\author{
Ali Marwan Hsb \\ Kantor Wilayah Kementerian Hukum dan HAM Sumatera Utara \\ Jalan Putri Hijau Nomor 4 Medan \\ Emai: ali_marwan@rocketmail.com
}

\begin{abstract}
Based on Article 11 Law Number 12 of 2011 on Legislation Making mentioned material contents of a Government Regulation in Lieu of Law are similar to those of a Law. This then becomes the question wheter what is meant by the material content includes material content regarding criminal provisions. In practice, after comes into force Law Number 12 of 2011 on Legislation Making, there are Government Regulation in Lieu of Law which contents criminal provisions. In this paper, it is stated that Government Regulation in Lieu of Law should not contents criminal provisions, because in addition contrary to reference techniques on Law Number 12 of 2011 on Legislation Making, loading of criminal provisions also has the potential violate human rights.
\end{abstract}

Keywords: Material Content, Criminal Provision, Government Regulation in Lieu of Law, Law.

\section{Abstrak}

Berdasarkan ketentuan Pasal 11 Undang-Undang Nomor 12 Tahun 2011 tentang Pembentukan Peraturan Perundang-undangan disebutkan bahwa materi muatan peraturan pemerintah pengganti undang-undang sama dengan materi muatan undang-undang. Hal ini kemudian menjadi pertanyaan apakah yang dimaksud dengan materi muatan tersebut termasuk materi muatan mengenai ketentuan pidana. Dalam praktiknya, setelah berlakunya Undang-Undang Nomor 12 Tahun 2011 tentang 
Pembentukan Peraturan Perundang-undangan, ada peraturan pemerintah pengganti undang-undang yang memuat ketentuan pidana. Dalam tulisan ini dinyatakan bahwa seyogianya peraturan pemerintah pengganti undang-undang tidak memuat ketentuan pidana karena selain bertentangan dengan teknik pengacuan dalam Undang-Undang Nomor 12 Tahun 2011 tentang Pembentukan Peraturan Perundang-undangan, pemuatan ketentuan pidana juga berpotensi melanggar hak asasi manusia.

Kata Kunci: Materi Muatan, Ketentuan Pidana, Peraturan Pemerintah Pengganti Undang-Undang, UndangUndang.

\section{Pendahuluan}

Dalam pembentukan peraturan perundang-undangan sudah menjadi kebiasaan dengan memuat ketentuan pidana dalam materi muatannya. Bahkan dalam Undang-Undang Nomor 12 Tahun 2011 tentang Pembentukan Peraturan Perundang-undangan ketentuan pidana merupakan salah satu isi dari batang tubuh suatu peraturan perundangundangan (jika diperlukan), setelah materi pokok yang diatur.

Dalam Pasal 15 Undang-Undang Nomor 12 Tahun 2011 tentang Pembentukan Peraturan Perundang-undangan disebutkan bahwa "materi muatan mengenai ketentuan pidana hanya dapat dimuat dalam: a. undang-undang; b. peraturan daerah provinsi; atau, c. peraturan daerah kabupaten/kota." Di mana untuk peraturan daerah provinsi dan peraturan daerah kabupaten/kota ada ketentuan bahwa ketentuan pidana dalam peraturan daerah berupa ancaman pidana kurungan paling lama 6 (enam) bulan atau pidana denda paling banyak Rp 50.000.000,- (lima puluh juta rupiah).

Yang menarik kemudian untuk dilihat adalah apakah peraturan pemerintah pengganti undang-undang dapat memuat ketentuan pidana. Hal ini perlu kemudian untuk dijawab dikarenakan secara hierarki, 
peraturan pemerintah pengganti undang-undang sejajar dengan undangundang. Bahkan dalam Pasal 11 Undang-Undang Nomor 12 Tahun 2011 tentang Pembentukan Peraturan Perundang-undangan disebutkan bahwa "materi muatan peraturan pemerintah pengganti undang-undang sama dengan materi muatan undang-undang".

Selain itu, kesamaan materi muatan peraturan pemerintah pengganti undang-undang dengan materi muatan undang-undang dikonfirmasi dalam Putusan Mahkamah Konstitusi Nomor 138/PUUVII/2009 bahwa peraturan pemerintah pengganti undang-undang dapat menimbulkan norma hukum baru yang kekuatan mengikatnya sama dengan undang-undang, sehingga Mahkamah Konstitusi berwenang untuk menguji peraturan pemerintah pengganti undang-undang secara materil karena materi muatannya sama dengan materi muatan undang-undang. ${ }^{1}$

Yang menjadi permasalahan kemudian adalah apakah kesamaan materi muatan peraturan pemerintah pengganti undang-undang dengan materi muatan undang-undang juga termasuk materi muatan mengenai ketentuan pidana.

\section{Pembahasan}

\section{Ketentuan Pidana dalam Peraturan Perundang-undangan}

Salah satu politik hukum dalam penyusunan suatu rancangan peraturan perundang-undangan merupakan penentuan sanksi pidana, baik penentuan pidana mati, pidana penjara, pidana kurungan, maupun pidana denda, termasuk pidana tambahannya. Terkait dengan penentuan pidana, Sudarto mengingatkan bahwa: ${ }^{2}$

1. penggunaan hukum pidana harus memperhatikan tujuan pembangunan nasional, yaitu mewujudkan masyarakat adil

${ }^{1}$ Ali Marwan Hsb, Keberadaan Mahkamah Konstitusi dan Putusannya, Medan: Enam Media, 2019, hlm. 65.

2 Suhariyono AR, "Perumusan Sanksi Pidana dalam Pembentukan Peraturan Perundang-undangan", Perspektif, Volume XVII, No. 1 Tahun 2012 Edisi Januari, hIm. 20 $-21$. 
makmur yang merata materil dan spiritual berdasarkan Pancasila. Sehubungan dengan itu, maka hukum pidana bertujuan untuk menanggulangi kejahatan demi adanya kesejahteraan dan pengayoman masyarakat;

2. perbuatan yang diusahan untuk dicegah atau ditanggulangi dengan hukum pidana harus merupakan perbuatan yang dikehendaki yaitu perbuatan yang mendatangkan kerugian atas warga masyarakat;

3. penggunaan hukum pidana harus pula memperhitungkan prinsip biaya dan hasil;

4. penggunaan hukum pidana harus pula memperhatikan kapasitas atau kemampuan daya kerja dari badan-badan penegak hukum, yaitu jangan sampai ada kelampauan beban tugas.

Pada umumnya, pembentuk peraturan perundang-undangan selalu mengatakan bahwa salah satu usaha penanggulangan kejahatan adalah dengan menggunakan hukum pidana dan sanksinya berupa pidana. Namun, dalam merumuskan ketentuan sanksi pidana dalam suatu peraturan perundang-undangan, pembentuk peraturan perundang-undangan harus berhati-hati dalam merumuskan ketentuan pidana yang rasional dan proporsional. ${ }^{3}$

Oleh karena itu, perlu batasan atau aturan mengenai bagaimana perumusan ketentuan pidana dalam pembentukan peraturan perundang-undangan. Terkait dengan ketentuan pidana dalam materi muatan peraturan perundang-undangan, sudah ada ketentuannya dalam lampiran II Undang-Undang Nomor 12 Tahun 2011 tentang Pembentukan Peraturan Perundang-undangan mulai angka 112 sampai dengan angka 126 sebagai berikut:

\footnotetext{
${ }^{3}$ Ibid., hlm. 21.
} 
112. ketentuan pidana memuat rumusan yang menyatakan penjatuhan pidana atas pelanggaran terhadap ketentuan yang berisi norma larangan atau norma perintah.

113. dalam merumuskan ketentuan pidana perlu diperhatikan asasasas umum ketentuan pidana yang terdapat dalam Buku Kesatu Kitab Undang-Undang Hukum Pidana, karena ketentuan dalam Buku Kesatu berlaku juga bagi perbuatan yang dapat dipidana menurut peraturan perundang-undangan lain, kecuali jika oleh undang-undang ditentukan lain (Pasal 103 Kitab Undang-Undang Hukum Pidana).

114. dalam menentukan lamanya pidana atau banyaknya denda perlu dipertimbangkan mengenai dampak yang ditimbulkan oleh tindak pidana dalam masyarakat serta unsur kesalahan pelaku;

115. ketentuan pidana ditempatkan dalam bab tersendiri, yaitu bab ketentuan pidana yang letaknya sesudah materi pokok yang diatur atau sebelum bab ketentuan peralihan. Jika bab ketentuan peralihan tidak ada, letaknya adalah sebelum bab ketentuan penutup.

116. jika di dalam peraturan perundang-undangan tidak diadakan pengelompokan bab per bab, ketentuan pidana ditempatkan dalam pasal yang terletak langsung sebelum pasal atau beberapa pasal yang berisi ketentuan peralihan. Jika tidak ada pasal yang berisi ketentuan peralihan, ketentuan pidana diletakkan sebelum pasal atau beberapa pasal yang berisi ketentuan penutup.

117. ketentuan pidana hany dimuat dalam undang-undang, peraturan daerah provinsi, dan peraturan daerah kabupaten/kota.

118. rumusan ketentuan pidana harus menyebutkan secara tegas norma larangan atau norma perintah yang dilanggar dan 
menyebutkan pasal atau beberapa pasal yang memuat norma tersebut. Dengan demikian perlu dihindari:

a. pengacuan kepada ketentuan pidana peraturan perundangundangan lain;

b. pengacuan kepada Kitab Undang-Undang Hukum Pidana, jika elemen atau unsur-unsur dari norma yang diacu tidak sama; atau

c. penyusunan rumusan sendiri yang berbeda atau tidak terdapat di dalam norma-norma yang diatur dalam pasal atau beberapa pasal sebelumnya, kecuali untuk undangundang mengenai tindak pidana khusus.

119. jika ketentuan pidana berlaku bagi siapapun, subjek dari ketentuan pidana dirumuskan dengan frasa setiap orang.

120. jika ketentuan pidana hanya berlaku bagi subjek tertentu, subjek itu dirumuskan secara tegas, misalnya, orang asing, pegawai negeri, saksi.

121. sehubungan adanya pembedaan antara tindak pidana kejahatan dan tindak pidana pelanggaran di dalam Kitab Undang-Undang Hukum Pidana, rumusan ketentuan pidana harus menyatakan secara tegas kualifikasi dari perbuatan yang diancam dengan pidana itu sebagai pelanggaran atau kejahatan.

122. rumusan ketentuan pidana harus menyatakan secara tegas kualifikasi pidana yang dijatuhkan bersifat kumulatif, alternatif, atau kumulatif alternatif.

123. perumusan dalam ketentuan pidana harus menunjukkan dengan jelas unsur-unsur perbuatan pidana bersifat kumulatif atau alternatif.

124. jika suatu peraturan perundang-undangan yang memuat ketentuan pidana akan diberlakusurutkan, ketentuan pidananya harus dikecualikan, mengingat adanya asas umum dalam Pasal 
1 ayat (1) Kitab Undang-Undang Hukum Pidana yang menyatakan bahwa ketentuan pidana tidak boleh berlaku surut.

125. ketentuan pidana bagi tindak pidana yang merupakan pelanggaran terhadap kegiatan bidang ekonomi dapat diatur tersendiri di dalam undang-undang yang bersangkutan, tetapi cukup mengacu kepada undang-undang yang mengatur mengenai tindak pidana ekonomi.

126. tindak pidana dapat dilakukan oleh orang-perorangan atau oleh korporasi. Pidana terhadap tindak pidana yang dilakukan oleh korporasi dijatuhkan kepada:

a. badan hukum antara lain perseroan, perkumpulan, yayasan, atau koperasi, dan/atau

b. pemberi perintah untuk melakukan tindak pidana atau yang bertindak sebagai pimpinan dalam melakukan tindak pidana.

\section{Peraturan Pemerintah Pengganti Undang-Undang yang Memuat Ketentuan Pidana}

Setelah berlakunya Undang-Undang Nomor 12 Tahun 2011 tentang Pembentukan Peraturan Perundang-undangan, sudah ada 9 (sembilan) peraturan pemerintah pengganti undang-undang yaitu:

1. Peraturan Pemerintah Pengganti Undang-Undang Nomor 1 Tahun 2013 tentang Perubahan Kedua atas Undang-Undang Nomor 24 Tahun 2003 tentang Mahkamah Konstitusi; ${ }^{4}$

2. Peraturan Pemerintah Pengganti Undang-Undang Nomor 1 Tahun 2014 tentang Pemilihan Gubernur, Bupati, dan Walikota; ${ }^{5}$

${ }^{4}$ Ditetapkan menjadi Undang-Undang Nomor 4 Tahun 2014 tentang Penetapan Peraturan Pemerintah Pengganti Undang-Undang Nomor 1 Tahun 2013 tentang Perubahan Kedua atas Undang-Undang Nomor 24 Tahun 2003 tentang Mahkamah Konstitus, kemudian dinyatakan bertentangan dengan Undang-Undang Dasar Negara Republik Indonesia Tahun 1945 dan tidak mempunyai kekuatan mengikat berdasarkan Putusan Mahkamah Konstitusi Nomor 1-2/PUU-XII/2014. 
3. Peraturan Pemerintah Pengganti Undang-Undang Nomor 2 Tahun 2014 tentang Perubahan atas Undang-Undang Nomor 23 Tahun 2014 tentang Pemerintahan Daerah; ${ }^{6}$

4. Peraturan Pemerintah Pengganti Undang-Undang Nomor 1 Tahun 2015 tentang Perubahan atas Undang-Undang Nomor 30 Tahun 2002 tentang Komisi Pemberantasan Tindak Pidana Korupsi; ${ }^{7}$

5. Peraturan Pemerintah Pengganti Undang-Undang Nomor 1 Tahun 2016 tentang Perubahan Kedua atas Undang-Undang Nomor 23 Tahun 2002 tentang Perlindungan Anak; ${ }^{8}$

6. Peraturan Pemerintah Pengganti Undang-Undang Nomor 1 Tahun 2017 tentang Akses Informasi Keuangan untuk Kepentingan Perpajakan; ${ }^{9}$

7. Peraturan Pemerintah Pengganti Undang-Undang Nomor 2 Tahun 2017 tentang Perubahan atas Undang-Undang Nomor 17 Tahun 2013 tentang Organisasi Kemasyarakatan; ${ }^{10}$

8. Peraturan Pemerintah Pengganti Undang-Undang Nomor 1 Tahun 2020 tentang Kebijakan Keuangan Negara dan Stabilitas

${ }^{5}$ Ditetapkan menjadi Undang-Undang Nomor 1 Tahun 2015 tentang Penetapan Peraturan Pemerintah Pengganti Undang-Undang Nomor 1 Tahun 2014 tentang Pemilihan Gubernur, Bupati, dan Walikota menjadi Undang-Undang.

${ }^{6}$ Ditetapkan menjadi Undang-Undang Nomor 2 Tahun 2015 tentang Penetapan Peraturan Pemerintah Pengganti Undang-Undang Nomor 2 Tahun 2014 tentang Perubahan atas Undang-Undang Nomor 23 Tahun 2014 tentang Pemerintahan Daerah menjadi Undang-Undang.

7 Ditetapkan menjadi Undang-Undang Nomor 10 Tahun 2015 tentang Penetapan Peraturan Pemerintah Pengganti Undang-Undang Nomor 1 Tahun 2015 tentang Perubahan atas Undang-Undang Nomor 30 Tahun 2002 tentang Komisi Pemberantasan Tindak Pidana Korupsi menjadi Undang-Undang.

8 Ditetapkan menjadi Undang-Undang Nomor 17 Tahun 2016 tentang Penetapan Peraturan Pemerintah Pengganti Undang-Undang Nomor 1 Tahun 2016 tentang Perubahan Kedua atas Undang-Undang Nomor 23 Tahun 2002 tentang Perlindungan Anak menjadi Undang-Undang.

${ }^{9}$ Ditetapkan menjadi Undang-Undang Nomor 9 Tahun 2017 tentang Penetapan Peraturan Pemerintah Pengganti Undang-Undang Nomor 1 Tahun 2017 tentang Akses Informasi Keuangan untuk Kepentingan Perpajakan menjadi Undang-Undang.

10 Ditetapkan menjadi Undang-Undang Nomor 16 Tahun 2017 tentang Penetapan Peraturan Pemerintah Pengganti Undang-Undang Nomor 2 Tahun 2017 tentang Perubahan atas Undang-Undang Nomor 17 Tahun 2013 tentang Organisasi Kemasyarakatan menjadi Undang-Undang. 
Sistem Keuangan untuk Penanganan Pandemi Corono Virus Disease 2019 (Covid-19) dan/atau dalam rangka Menghadapi Ancaman yang Membahayakan Perekonomian Nasional dan/atau Stabilitas Sistem Keuangan;

9. Peraturan Pemerintah Pengganti Undang-Undang Nomor 2 Tahun 2020 tentang Perubahan Ketiga atas Undang-Undang Nomor 1 Tahun 2015 tentang Penetapan Peraturan Pemerintah Pengganti Undang-Undang Nomor 1 Tahun 2014 tentang Pemilihan Gubernur, Bupati, dan Walikota menjadi UndangUndang.

Dari kesembilan peraturan pemerintah pengganti undangundang tersebut, 3 (tiga) diantaranya memuat ketentuan pidana, yaitu Peraturan Pemerintah Pengganti Undang-Undang Nomor 1 Tahun 2014 tentang Pemilihan Gubernur, Bupati, dan Walikota, Peraturan Pemerintah Pengganti Undang-Undang Nomor 1 Tahun 2016 tentang Perubahan Kedua atas Undang-Undang Nomor 23 Tahun 2002 tentang Perlindungan Anak, dan Peraturan Pemerintah Pengganti Undang-Undang Nomor 2 Tahun 2017 tentang Perubahan atas Undang-Undang Nomor 17 Tahun 2013 tentang Organisasi Kemasyarakatan.

Bahkan Peraturan Pemerintah Pengganti Undang-Undang Nomor 1 Tahun 2016 tentang Perubahan Kedua atas UndangUndang Nomor 23 Tahun 2002 tentang Perlindungan Anak, hanya berisi ketentuan pidana yang mengubah pasal ketentuan pidana dalam Undang-Undang Nomor 23 Tahun 2002 tentang Perlindungan Anak.

Hal ini mengindikasikan bahwa pembentuk undang-undang yaitu Dewan Perwakilan Rakyat dan Presiden mengamini bahwa peraturan pemerintah pengganti undang-undang boleh memuat ketentuan pidana. Karena dari ketiga peraturan pemerintah pengganti undang-undang yang memuat ketentuan pidana tersebut, 
semuanya disetujui oleh Dewan Perwakilan Rakyat untuk ditetapkan menjadi undang-undang.

\section{Pemuatan Ketentuan Pidana dalam Peraturan Pemerintah Pengganti Undang-Undang}

Ketentuan Pasal 11 Undang-Undang Nomor 12 Tahun 2011 tentang Pembentukan Peraturan perundang-undangan menegaskan bahwa "materi muatan peraturan pemerintah pengganti undangundang sama dengan materi muatan undang-undang". Jika mengacu pada pola pikir yang terkandung dalam ketentuan pasal ini maka materi muatan peraturan pemerintah pengganti undang-undang juga berisi hal-hal yang tercantum sebagai materi muatan yang harus diatur dalam undang-undang, termasuk pula dapat memuat ketentuan pidana. Pola pikir ini dapat diuji rasionalitasnya dengan argumentasi bahwa peraturan pemerintah pengganti undang-undang dibentuk dalam kondisi yang abnormal, sedangkan undang-undang dibentuk dalam kondisi yang normal, sehingga materi muatan peraturan pemerintah pengganti undang-undang seyogianya berbeda dengan materi muatan undang-undang. ${ }^{11}$

Menurut Reza Fikri Febriansyah, salah satu perbedaan yang seharusnya muncul antara peraturan pemerintah pengganti undangundang adalah hendaknya peraturan pemerintah pengganti undangundang tidak memuat ketentuan pidana dengan alasan bahwa peraturan pemerintah pengganti undang-undang dibuat untuk menghadapi kegentingan yang memaksa atau tidak berorientasi jangka panjang dan tidak melibatkan parlemen sebagai unsur perwakilan rakyat dalam proses pembentukannya. Pencantuman suatu ketentuan pidana sangat berkaitan dengan prinsip-prinsip asas legalitas. Di mana, dalam teori hukum pidana, salah satu aspek

${ }^{11}$ Reza Fikri Febriansyah, "Eksistensi dan Prospek Pengaturan Perppu dalam Sistem Norma Hukum Negara Republik Indonesia”, Jurnal Legislasi Indonesia, Vol. 6, No. 4 - Desember 2009, hlm. 677 - 678. 
penting mengenai asas legalitas adalah dirumuskannya suatu ketentuan perundang-undangan pidanan melalui proses legitimasi yang demokratis ke dalam undang-undang dalam arti formal. Dalam teori ilmu perundang-undang, undang-undang dalam arti formal adalah norma-norma hukum yang selalui dibentuk oleh suatu lembaga legislatif. Hal inilah yang kemudian mendasari bahwa materi muatan mengenai ketentuan pidana hanya dapat dimuat dalam undang-undang, peraturan daerah provinsi, dan peraturan daerah kabupaten/kota. Sehingga menjadi jelaslah bahwa seyogianya peraturan pemerintah pengganti undang-undang tidak dapat memuat ketentuan pidana karena peraturan pemerintah pengganti undangundang tidak termasuk dalam kategori norma-norma hukum yang dibentuk oleh suatu lembaga legislatif. ${ }^{12}$

Terkait dengan boleh tidaknya peraturan pemerintah pengganti undang-undang memuat ketentuan pidana, penulis setuju dengan pendapat yang menyatakan bahwa hendaknya peraturan pemerintah pengganti undang-undang tidak memuat ketentuan pidana. Selain alasan yang disampaikan oleh Reza Fikri Febriansyah tersebut, ada beberapa alasan lain yang menurut penulis menjadi alasan tidak bolehnya peraturan pemerintah pengganti undangundang memuat ketentuan pidana, yaitu:

1. pemakaian kata "hanya" dalam ketentuan Pasal 15 UndangUndang Nomor 12 Tahun 2011 tentang Pembentukan Peraturan Perundang-undangan yang menyatakan bahwa "materi muatan mengenai ketentuan pidana hanya dapat dimuat dalam: a. undang-undang; b. peraturan daerah provinsi; atau, c. peraturan daerah kabupaten/kota." Berdasarkan Kamus Besar Bahasa Indonesia disebutkan arti dari kata "hanya" adalah tidak lebih dari atau tidak lain dari. Jika dihubungkan dengan ketentuan Pasal 15 tersebut, maka tidak ada peraturan

12 Ibid., hlm. 678 - 679. 
perundang-undangan lain yang boleh memuat ketentuan pidana selain undang-undang, peraturan daerah provinsi, dan peraturan daerah kabupaten/kota.

2. ketentuan yang sering menjadi dasar untuk menyatakan bahwa peraturan pemerintah pengganti undang-undang dapat memuat ketentuan pidana yaitu Pasal 11 Undang-Undang Nomor 12 Tahun 2011 tentang Pembentukan Peraturan Perundangundangan bahwa "materi muatan peraturan perundangundangan sama dengan materi muatan undang-undang". Di mana materi muatan undang-undang diatur dalam Pasal 9 Undang-Undang Nomor 12 Tahun 2011 tentang Pembentukan Peraturan Perundang-undangan bahwa "materi muatan yang harus diatur dengan undang-undang berisi: a. pengaturan lebih lanjut mengenai ketentuan Undang-Undang Dasar Negara Republik Indonesia Tahun 1945; b. perintah suatu undangundang untuk diatur dengan undang-undang; c. pengesahan perjanjian internasional tertentu; $d$. tindak lanjut atas putusan Mahkamah Konstitusi; dan/atau e. pemenuhan kebutuhan hukum dalam masyarakat. Sedangkan ketentuan mengenai materi muatan mengenai ketentuan pidana diatur dalam Pasal 15 Undang-Undang Nomor 12 Tahun 2011 tentang Pembentukan Peraturan Perundang-undangan.

Jika mengacu kepada teknik pengacuan dalam Lampiran II Undang-Undang Nomor 12 Tahun 2011 tentang Pembentukan Peraturan Perundang-undangan angka 279 menyebutkan bahwa "hindari pengacuan ke pasal atau ayat yang terletak setelah pasal atau ayat bersangkutan". Oleh karena itu, jika menggunakan teknik pengacuan, maka yang dimaksud dengan materi muatan peraturan pemerintah pengganti undang-undang sama dengan materi muatan undang-undang adalah mengacu kepada materi muatan undang-undang dalam Pasal 9 Undang- 
Undang Nomor 12 Tahun 2011 tentang Pembentukan Peraturan Perundang-undangan, bukan mengacu kepada materi muatan ketentuan pidana dalam undang-undang sebagaimana diatur dalam Pasal 15 Undang-Undang Nomor 12 Tahun 2011 tentang Pembentukan Peraturan Perundangundangan. Karena berdasarkan teknik pengacuan, pengacuan dilakukan kepada pasal sebelumnya bukan kepada pasal setelahnya.

3. pemuatan ketentuan pidana dalam peraturan pemerintah pengganti undang-undang berpotensi melanggar hak asasi manusia. Peraturan pemerintah pengganti undang-undang ditetapkan oleh Presiden dalam hal ihwal kegentingan yang memaksa dan sifatnya hanya sementara. Di mana, peraturan pemerintah pengganti undang-undang harus diajukan kepada Dewan Perwakilan Rakyat untuk disetujui atau ditolak untuk ditetapkan menjadi undang-undang. Apabila bila disetujui, maka peraturan pemerintah pengganti undang-undang tersebut ditetapkan menjadi undang-undang. Dan apabila ditolak, maka peraturan pemerintah pengganti undang-undang tersebut dicabut. Berdasarkan hal tersebut, maka keberadaan peraturan pemerintah undang-undang tergantung kepada Dewan Perwakilan Rakyat.

Apabila seseorang kemudian dikenakan ketentuan pidana dan sudah menjalani proses pemidanaan berdasarkan ketentuan pidana dalam peraturan pemerintah pengganti undang-undang, maka tidak akan menjadi masalah apabila peraturan pemerintah pengganti undang-undang tersebut ditetapkan menjadi undang-undang. Akan terjadi masalah apabila kemudian peraturan pemerintah pengganti undang-undang yang menjadi dasar pemidanaannya kemudian tidak disetujui oleh Dewan Perwakilan Rakyat dan kemudian peraturan 
pemerintah pengganti undang-undang tersebut kemudian dicabut. Bagaimana kemudian nasib dari orang yang sudah dipidana tersebut?

Tentu hal ini berpotensi melanggar hak asas manusia, khususnya Pasal 28D ayat (1) Undang-Undang Dasar Negara Republik Indonesia Tahun 1945 bahwa "setiap orang berhak atas pengakuan, jaminan, perlindungan, dan kepastian hukum yang adil serta perlakuan yang sama di hadapan hukum".

Oleh karena itu, pemuatan ketentuan pidana dalam peraturan pemerintah pengganti undang-undang tentunya tidak memberikan kepastian hukum karena bisa saja peraturan pemerintah pengganti undang-undang tersebut tidak disetujui oleh Dewan Perwakilan Rakyat.

\section{Kesimpulan}

Berdasarkan pembahasan di atas, maka dapat disimpulkan bahwa dalam praktik pembentukan peraturan pemerintah pengganti undangundang dapat ditemukan peraturan pemerintah pengganti undang-undang yang memuat ketentuan pidana. Namun, ke depan disarankan agar dalam peraturan pemerintah pengganti undang-undang hendaknya tidak lagi memuat ketentuan pidana, dikarenakan peraturan pemerintah pengganti undang-undang hanya bersifat sementara waktu dan berpotensi melanggar hak asasi manusia karena peraturan pemerintah pengganti undang-undang dapat saja tidak ditetapkan menjadi undang-undang apabila ditolak oleh Dewan Perwakilan Rakyat. 


\section{Daftar Pustaka}

\section{BUKU DAN JURNAL}

Ali Marwan Hsb, Keberadaan Mahkamah Konstitusi dan Putusannya, Medan: Enam Media, 2019.

Reza Fikri Febriansyah, "Eksistensi dan Prospek Pengaturan Perppu dalam Sistem Norma Hukum Negara Republik Indonesia”, Jurnal Legislasi Indonesia, Vol. 6, No. 4 - Desember 2009.

Suhariyono AR, "Perumusan Sanksi Pidana dalam Pembentukan Peraturan Perundang-undangan", Perspektif, Volume XVII, No. 1 Tahun 2012 Edisi Januari.

\section{PERATURAN PERUNDANG-UNDANGAN}

Peraturan Pemerintah Pengganti Undang-Undang Nomor 1 Tahun 2013 tentang Perubahan Kedua atas Undang-Undang Nomor 24 Tahun 2003 tentang Mahkamah Konstitusi.

Peraturan Pemerintah Pengganti Undang-Undang Nomor 1 Tahun 2014 tentang Pemilihan Gubernur, Bupati, dan Walikota.

Peraturan Pemerintah Pengganti Undang-Undang Nomor 1 Tahun 2015 tentang Perubahan atas Undang-Undang Nomor 30 Tahun 2002 tentang Komisi Pemberantasan Tindak Pidana Korupsi.

Peraturan Pemerintah Pengganti Undang-Undang Nomor 1 Tahun 2016 tentang Perubahan Kedua atas Undang-Undang Nomor 23 Tahun 2002 tentang Perlindungan Anak.

Peraturan Pemerintah Pengganti Undang-Undang Nomor 1 Tahun 2017 tentang Akses Informasi Keuangan untuk Kepentingan Perpajakan.

Peraturan Pemerintah Pengganti Undang-Undang Nomor 1 Tahun 2020 tentang Kebijakan Keuangan Negara dan Stabilitas Sistem Keuangan untuk Penanganan Pandemi Corono Virus Disease 2019 (Covid-19) dan/atau dalam rangka Menghadapi Ancaman 
yang Membahayakan Perekonomian Nasional dan/atau Stabilitas Sistem Keuangan.

Peraturan Pemerintah Pengganti Undang-Undang Nomor 2 Tahun 2014 tentang Perubahan atas Undang-Undang Nomor 23 Tahun 2014 tentang Pemerintahan Daerah.

Peraturan Pemerintah Pengganti Undang-Undang Nomor 2 Tahun 2017 tentang Perubahan atas Undang-Undang Nomor 17 Tahun 2013 tentang Organisasi Kemasyarakatan.

Peraturan Pemerintah Pengganti Undang-Undang Nomor 2 Tahun 2020 tentang Perubahan Ketiga atas Undang-Undang Nomor 1 Tahun 2015 tentang Penetapan Peraturan Pemerintah Pengganti Undang-Undang Nomor 1 Tahun 2014 tentang Pemilihan Gubernur, Bupati, dan Walikota menjadi Undang-Undang.

Undang-Undang Nomor 12 Tahun 2011 tentang Pembentukan Peraturan Perundang-undangan. 